\title{
Indoor Nanoparticles Measurements in Workplace Environment: The Case of Printing and Photocopy Center
}

\author{
Irena Grgić, ${ }^{1, *}$ Jožica Bratec ${ }^{1,2}$ and Marija Bešter Rogač² \\ ${ }^{1}$ Department of Analytical Chemistry, National Institute of Chemistry, Hajdrihova 19, SI-1000 Ljubljana, Slovenia \\ ${ }^{2}$ University of Ljubljana, Faculty of Chemistry and Chemical Technology, Večna pot 113, SI-1000 Ljubljana, Slovenia \\ *Corresponding author: E-mail: irena.grgic@ki.si
}

Received: 20-01-2016

\begin{abstract}
In recent studies, laser printers and photocopy machines have been identified as important sources of indoor air pollution with fine and ultrafine particles. In this work, the indoor pollution of a printing and photocopy center in Ljubljana, Slovenia was investigated. The particle number concentration time series and the particle size distributions were measured continuously for a period of one month by a scanning mobility particle sizer (SMPS). Our measurements clearly showed that during operating hours the total number concentration of nanoparticles (size between 15 and $750 \mathrm{~nm}$ ) increased in both working rooms with laser printers as well as in a room with photocopy machines. In rooms with laser printers the bimodal particle size distribution was frequently observed (i.e. max. at ca. 20 or $30 \mathrm{~nm}$ and at ca. $100 \mathrm{~nm}$ ), with the aged particles persisted in the room over the night and over the weekend. In the photocopy room the situation was different, again with a sharp increase in concentration of small particles $(\mathrm{ca} 20 \mathrm{~nm}$ ) and their growth to bigger sizes, but after closing a decrease to the background concentration. The results undoubtedly proved that the fast increase in nanoparticles (size below $50 \mathrm{~nm}$ ) was associated with processes, the intense laser printing and photocopying activity. Our study also confirmed that the ventilation of the room is a very important factor which affects the life time of aged nanoparticle in the indoor environment.
\end{abstract}

Keywords: Indoor air quality, indoor environment, ultrafine and fine particles, laser printer emissions, photocopier emissions

\section{Introduction}

Nowadays we spend the majority of our lifetime, professional and private, in different indoor environments. In addition to the influence of outdoor pollution, which can penetrate into the buildings, various different sources can contribute to indoor pollution. Electronic devices, such as personal computers, printers, photocopy machines, which are nearly vital in our lives, can importantly influence the indoor air quality. Therefore, the emissions from such devices are of big health concern. Many studies have reported that laser printers and photocopy machines emit besides volatile organic compounds (VOCs) and ozone, also fine and ultrafine particles. ${ }^{1-6}$ It is also known that the major fraction of particles emitted during operation of laser printers represents ultrafine particles (i.e. nanoparticles) with the size range below $100 \mathrm{~nm}$ with an average size of about $30-50 \mathrm{~nm} .^{7,8}$

The studies on indoor pollution due to the emissions of nanoparticles from laser printers and photocopy machi- nes are mostly related to the particle concentrations and size distributions ${ }^{1,9,10}$ and to possible formation mechanisms. ${ }^{8} 10$ Measurements on particle emissions in the realroom environment ${ }^{7,10}$ and studies on modeled office environment can be found as well; ${ }^{5}$ the influence of different parameters, such as fuser roller temperature on the emissions of laser printers was also studied. ${ }^{7,11}$ The majority of particles emitted from laser printers is volatile and of secondary nature, i.e. formed in the air through the reactions of VOCs and semi volatile organic compounds (SVOCs) originating from paper and/or hot toner with ozone. ${ }^{8}$ In addition, Barthel et al. ${ }^{12}$ reported on elemental analysis of fine and ultrafine particles, and the elements identified (e.g. $\mathrm{Si}, \mathrm{S}, \mathrm{Cl}, \mathrm{Ca}, \mathrm{Ti}, \mathrm{Cr}, \mathrm{Fe}$ ) were mainly connected with toner and paper.

Further, the studies have also pointed out the potential health hazards associated with nanoparticles emitted during laser printing and photocopying operation. ${ }^{13-15}$ For example, it has been shown that already short-term expo- 
sures (i.e. $6 \mathrm{~h}$ ) to modest concentrations $(5,000-30,000$ particles $\mathrm{cm}^{-3}$ ) of nanoparticles emitted during photocopying induced statistically significant increases in systemic oxidative stress and upper airway inflammation. ${ }^{14}$ In addition, occupational and consumer risk for nanoparticles from laser printers have been estimated ${ }^{16}$ and their toxicological effects have been recognized by World Health Organization as well. ${ }^{17}$

In this work, the indoor pollution with fine and ultrafine particles in a company for spatial informatics and graphic design from Ljubljana, Slovenia dealing with different services, among which are also printing and photocopynig, was investigated for the first time. The particle number concentrations and the particle size distributions were measured continuously in a period of one month in three working rooms (in each for about 10 days) where different hardcopy devices were in use.

\section{Experimental}

\section{1. Instrumentation}

A Scanning Mobility Particle Sizer spectrometer (SMPS 3936L75, TSI) was used for continuous measurements of submicrometer particle number concentrations and size distributions in the range from $15 \mathrm{~nm}$ to $750 \mathrm{~nm}$ (scan up time $180 \mathrm{~s}$; retrace time $15 \mathrm{~s}$ ). The SMPS consists of an Electrostatic Classifier with a long Differential Mobility Analyzer (DMA, 3081), negatively charged high voltage controller and Impactor nozzle $(0.071 \mathrm{~cm})$, which is coupled to a Condensation Particle Counter (CPC 3775). The solvent for the CPC was $n$-butanol (Reagent Grade). The SMPS was set to measure every 5 minutes during period from February 25 to March 28, 2014. A sample flow rate of $0.3 \mathrm{~L} \mathrm{~min}^{-1}$ was used with a sheath flow of $3 \mathrm{~L} \mathrm{~min}^{-1}$.

\section{2. Sampling Sites}

Measurements were performed in a company for spatial informatics and graphic design from Ljubljana, Slovenia in three different working rooms dealing with different kind of services (e.g. digital printing, graphic design, scanning, photocopying). From a schematic illustration (Figure 1) it can be seen that in the first working room (Room 1, size: $5.5 \mathrm{~m} \times 7.2 \mathrm{~m} \times 3.2 \mathrm{~m}$ ) the SMPS stand on a table at $0.75 \mathrm{~m}$ from the ground with the sampling tube at a distance of about $2 \mathrm{~m}$ to the laser printer (Konika Minolta C7000); in this room was also one bigger inkjet plotter (Inkjet Cannon iPF8000S) at the distance of about $3 \mathrm{~m}$ to the SMPS. In the second room (Room 2, size: $10 \mathrm{~m} \times 7.3 \mathrm{~m} \times 3.20 \mathrm{~m}$ ) the SMPS was about $3 \mathrm{~m}$ from the laser printer (Laser Xerox Colour 560) (Figure 1); there were also four bigger inkjet plotters of different producers (Roland Versa CAMM, SureColour S 30610, Hp designjet 5500 and UV-160 UV printer Mimaki). In the third room (Room 3, size: $5.2 \mathrm{~m}$ $\times 7.5 \mathrm{~m} \times 3.2 \mathrm{~m}$ ) there were two photocopy machines (Ducacolors 252 and Kyocera mita, KM4530). The SMPS was in the corner on the shelf at about $0.75 \mathrm{~m}$ from the ground with the sampling tube at about $2-3 \mathrm{~m}$ to the machines (Figure 1).

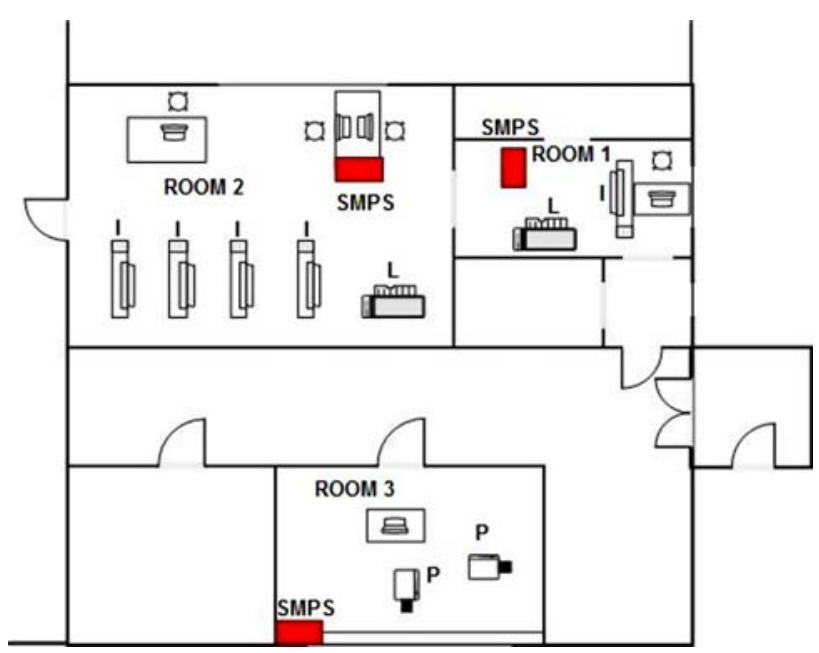

Figure 1: Schematic illustration of three investigated working rooms in a company for spatial informatics and graphic design in Ljubljana, Slovenia with denoted positions of SMPS in each room as well as printers and copiers. L: laser printer, P: photocopy machine and I: inkjet plotter.

The continuous measurements were performed for one month, the first 10 days in Room 1 with one laser printer, then the SMPS was moved into Room 2 with one laser printer as well, and the last 7 days the measurements were performed in Room 3 with two photocopy machines (Figure 1). The ventilation in Room 1 and Room 3 was carried out only by opening the windows when necessary, mostly in the morning; while in Room 2 there was no window at all, the only access of fresh air, better said the mixing of the air was possible through the door between the two rooms. The working time from Monday to Thursday was from 8:00 to 17:00, on Friday from 8:00 to 16:00, while during the weekend the company was closed.

\section{Results and Discussion}

\section{1. Results of SMPS Measurements in Room 1}

The continuous measurements of fine and ultrafine particles in the company for spatial informatics and graphic design from Ljubljana were started in the Room 1 (Figure 1) at 16:00 on February 25 and finished at 14:00 on March 6, 2014. The typical particle number size distribu- 
tions for all days including the weekend are shown in Figure 2. In general, it is evident that the concentration of nanoparticles significantly increased during working hours, i.e. immediately after 8:00. In most cases a bimodal size distribution was observed: first one is a mode with particles of a diameter at around $30 \mathrm{~nm}$ and the second one with partic-
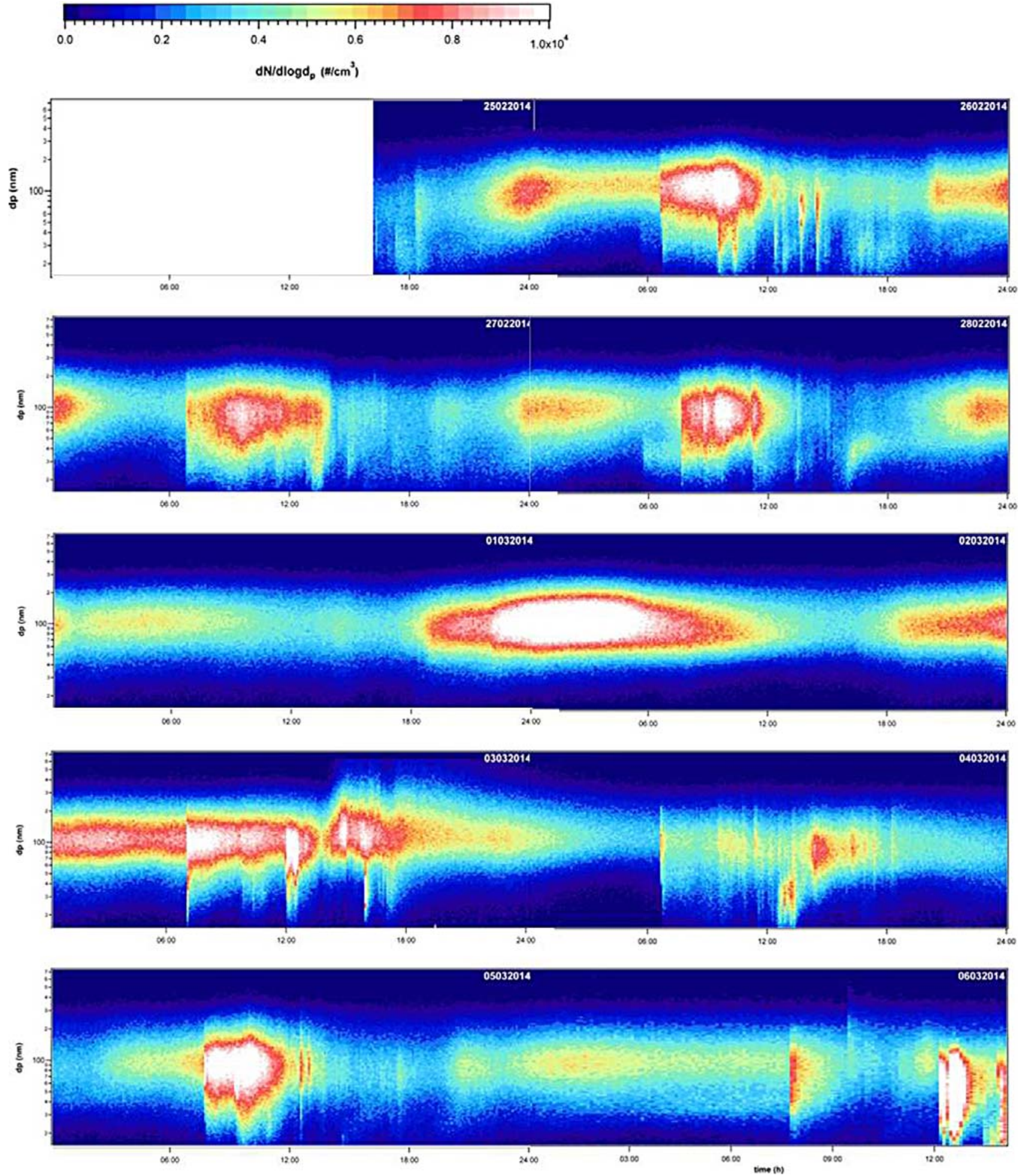

Figure 2: Number concentration (particle $\mathrm{cm}^{-3}$ ) and size distribution of the particles continuously measured in Room1 of the company of spatial informatics and graphic design in Ljubljana, Slovenia from February 25 to March 6, 2014. White color represents the concentrations above $10 \times 10^{3}$ particle $\mathrm{cm}^{-3}$. 
les between 50 and $150 \mathrm{~nm}$ (maximum at around $100 \mathrm{~nm}$ ). Strong emissions of smaller particles can be undoubtedly seen especially on February 26, March 3 and March 4, 2014. Although the concentration of particles decreased during the nonworking time it is evident that they persisted in the room during the night and also during the weekend (March 1 and 2, 2014); these were mostly aged particles with the average particle size of around $100 \mathrm{~nm}$.

The characteristic total number concentration of particles between 15 and $750 \mathrm{~nm}$ measured on March 5, 2014 (Figure 3 a) show a clear diurnal variation; it can be seen that the concentration raised steeply after 8:00 in the morning, reached the highest concentration during the high load of work between 8:00 and 12:00, and decreased to below $3.0 \times 10^{3}$ particle $\mathrm{cm}^{-3}$ at 15:00. In the Room 1 the average total number concentration for all working days during the working hours (from 8:00 to 17:00) was around $5.1 \times 10^{3}$ particle $\mathrm{cm}^{-3}$, while the highest measured concentration during printing was around $17 \times 10^{3}$ particle $\mathrm{cm}^{-3}$ determined at 12:30 on March 6, 2014. Our measurements also reveal that the concentration of particles (i.e. background concentration) during nonworking time (no printing) was about $2 \times 10^{3}$ particle $\mathrm{cm}^{-3}$. Obviously, the elevated concentrations did not decrease always to the background concentration as it can be seen from the results over the night and also from the results for the weekend when the average concentration for Saturday March 1 was about $3.7 \times 10^{3}$ particle $\mathrm{cm}^{-3}$ and for Sunday even higher (ca. $4.6 \times 10^{3}$ particle $\mathrm{cm}^{-3}$ ). However, it can be assumed that these were aged particles of the size of about $100 \mathrm{~nm}$ (Figure 2) expressing higher concentrations after 18:00 in the evening until the next day morning. Observed situation can be ascribed to the absence of any ventilation during the weekend. In any case, the average number particle concentration in the Room 1 during working time was more than 2 times higher than during nonworking time, and the maximal measured number particle concentrations were more than 5 times higher than the background concentrations.

\section{2. Results of SMPS Measurements in Room 2}

The SMPS was afterward moved into the Room 2 (Figure 1) where the continuous particle measurements were conducted from March 7 to March 17, 2014. From Figure 4 representing size-resolved particle number concentration time series for 10 days, it is evident that in general the indoor pollution with particles was similar as in Room 1, but still with some important differences. As in Room 1 the concentration of nanoparticles raised immediately in the morning when the laser printer and other electronic devices were turned on. During working days the bimodal size distribution was frequently observed, i.e. particles with a diameter below $50 \mathrm{~nm}$ (maximum at around 20 or $30 \mathrm{~nm}$ ) and particles between 50 and $200 \mathrm{~nm}$ with maximum at around $100 \mathrm{~nm}$ (e.g. March 10 and 12, 2014 in Figure 4). The aging of particles was evident every working day; for example very clearly at around 14:00 on

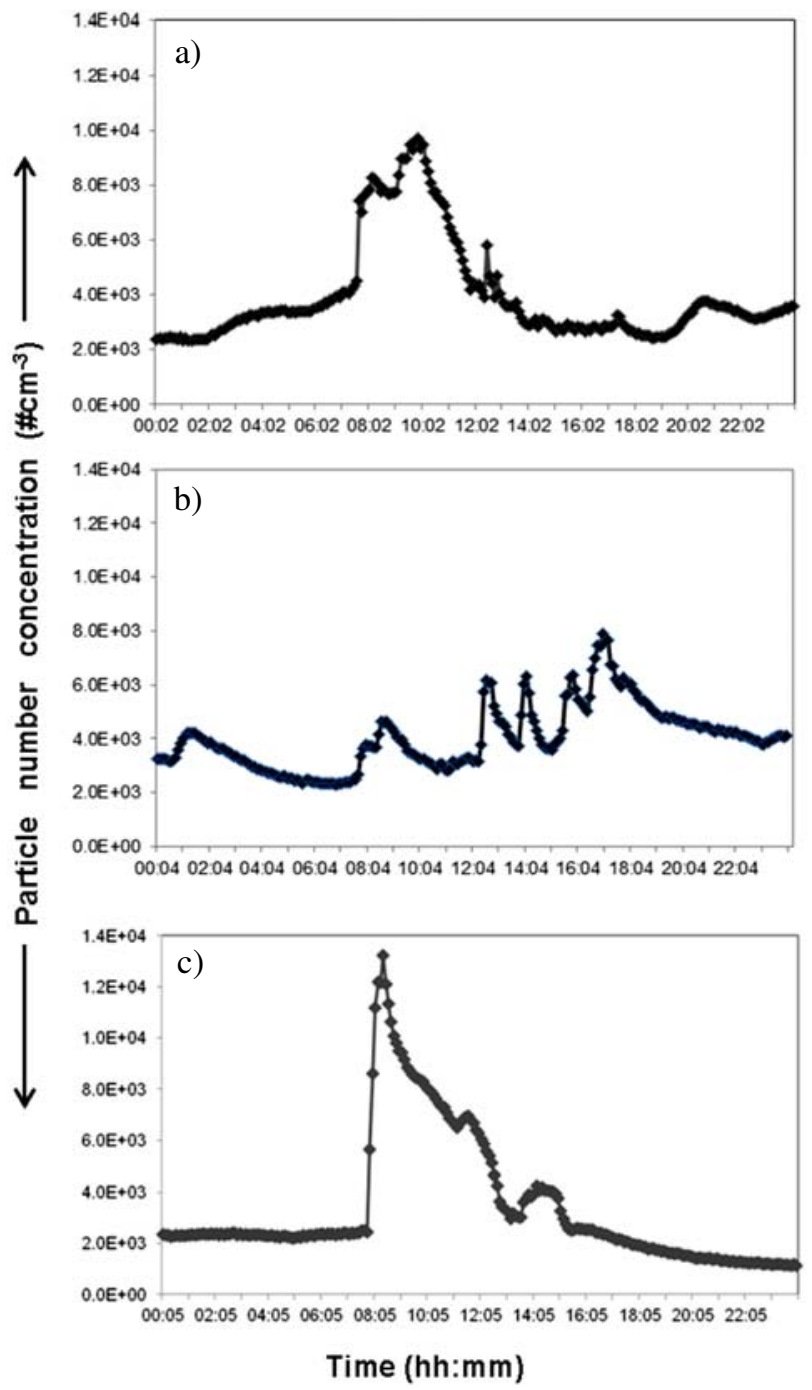

Figure 3: a) Total number concentration of particles between 15 and $750 \mathrm{~nm}$ measured on March 5, 2014 in the Room1 b) on March 10, 2014 in the Room 2 and c) in the Room 3, on March 21, 2014.

March 10, 2014, at 18:00 on March 12 and at 17:00 on March 14, 2014 the small particles started to grow until they reached the stable dimension of about $100 \mathrm{~nm}$. It is also obvious that on March 12 and 14 very high concentrations, i.e. higher than $10 \times 10^{3}$ particle $\mathrm{cm}^{-3}$ of nanoparticles of the size below $20 \mathrm{~nm}$ were emitted most probably due to the intensive laser printing. In this working room, the concentration of particles remained high also over the night, and was even more pronounced, especially between March 11 and 14. In addition, during the weekend (March 8, 9 and 15, 2014 in Figure 4) the concentrations of aged particles were also elevated. 


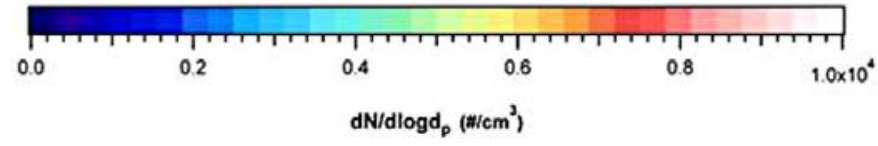
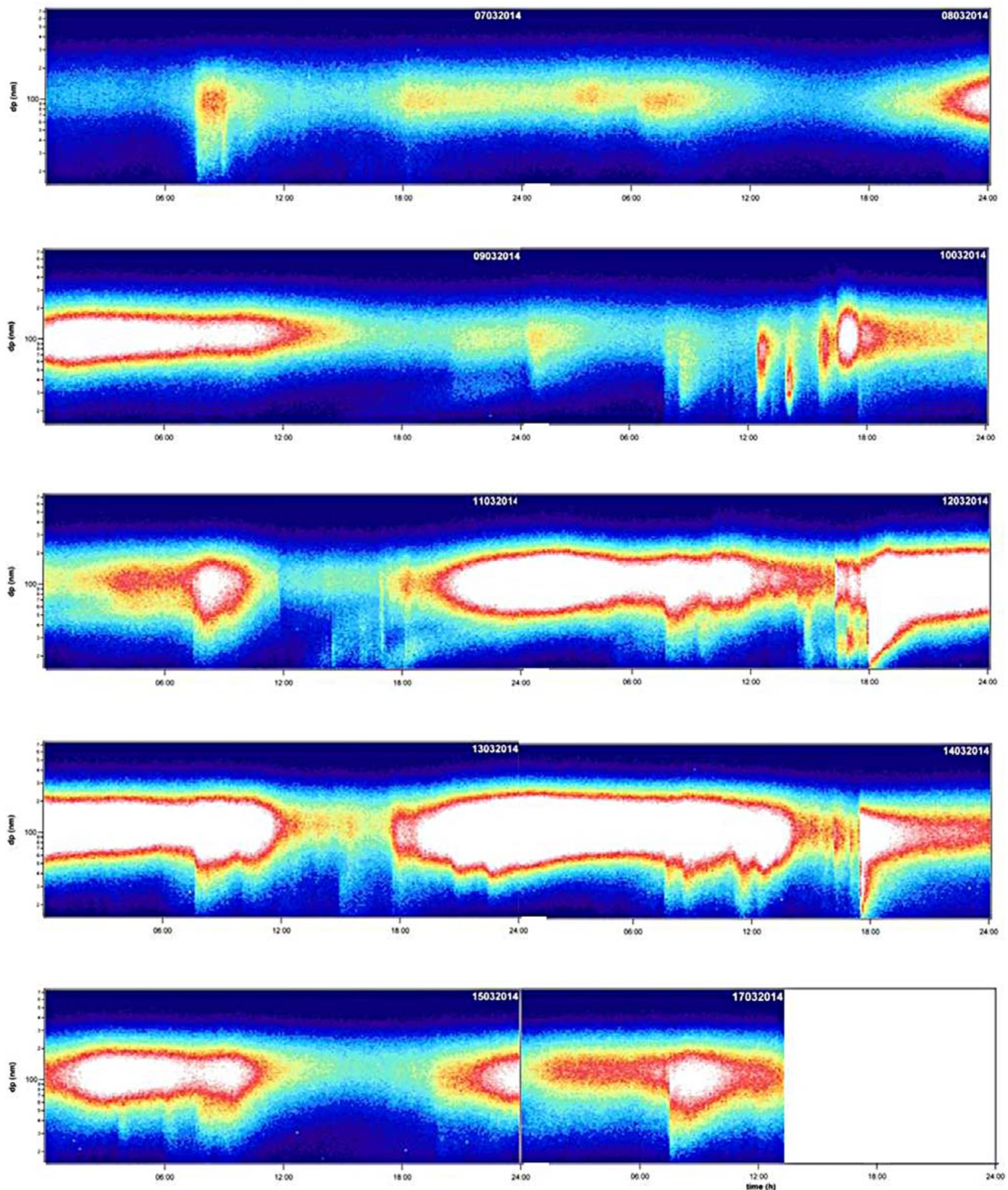

Figure 4: Number concentration (particle $\mathrm{cm}^{-3}$ ) and size distribution of the particles continuously measured in Room 2 of the company of spatial informatics and graphic design in Ljubljana, Slovenia from March 7 to March 17, 2014. White color represents the concentrations above $10 \times 10^{3}$ particle $\mathrm{cm}^{-3}$. 
From the total particle number concentration for the working day March 10, 2014 (Figure 3 b) it can be seen a typical diurnal variation with a clear increase in the concentration after 8:00, but also with obvious peaks during working hours which were most likely connected with the intensive laser printing. The maximal concentration this day (about $8 \times 10^{3}$ particle $\mathrm{cm}^{-3}$ ) was reached at about 17:00, it then decreased to about $4 \times 10^{3}$ particle $\mathrm{cm}^{-3}$ and remained practically constant over the night. The average total number concentration for all working days during the working hours was about $6.5 \times 10^{3}$ particle $\mathrm{cm}^{-3}$ with the highest concentration of $17 \times 10^{3}$ particle $\mathrm{cm}^{-3}$ measured on March 12, 2014 one hour after closing. The concentration of particles then very slowly decreased, but was still high also over the night, and this situation is very typical for this room. The reason was without doubt due to absence of ventilation; the only possible circulation of air was through the door which connects the two rooms only. Over the weekend, the number concentration of particles remained high, i.e. on March 8 the average total number concentration was about $3.3 \times 10^{3}$ particle $\mathrm{cm}^{-3}$, on March 9 about $4.8 \times 10^{3}$ particle $\mathrm{cm}^{-3}$, on March 15 about $5 \times 10^{3}$ particle $\mathrm{cm}^{-3}$ and on March 16 about $4.6 \times 10^{3}$ particle $\mathrm{cm}^{-3}$. Anyway, it was found that over the weekends during a certain period of a day, usually after 11:00 and not later than 20:00, the concentration of particles decreased below $3 \times 10^{3}$ particle $\mathrm{cm}^{-3}$. Due to absence of ventilation the conditions in this room were worse than in the Room 1; even during nonworking hours the concentrations of the particles between 50 and $200 \mathrm{~nm}$ with maximum at around $100 \mathrm{~nm}$ remained elevated, sometimes the total number concentrations exceeded $10 \times 10^{3}$ particle $\mathrm{cm}^{-3}$.

\section{3 Results of SMPS Measurements in Room 3}

The last 7 days the continuous particle measurements were conducted in the Room 3 where two photocopy machines were situated (Figure 1). From Figure 5, where the results for 5 working days are shown it is immediately clear that the conditions were distinctly different than in the other two working rooms. The background concentration of particles, i.e. before 8:00 were much lower, typically around $1 \times 10^{3}$ particle $\mathrm{cm}^{-3}$ while during the weekend (March 22 and 23, 2014; not shown in Figure 5) the concentrations were even lower (as low as $0.6 \times$ $10^{3}$ particle $\mathrm{cm}^{-3}$ ). When the photocopiers started to work the concentrations of ultrafine particles sharply increased. It can be seen that the particles of about $20 \mathrm{~nm}$ to $30 \mathrm{~nm}$ (e.g. see March 20 and 21, 2014) were emitted, growing later to bigger particles of about $80 \mathrm{~nm}$. On March 24, 2014 at around 16:00 a very drastic emission of particles smaller than $20 \mathrm{~nm}$ can be seen; after that they pretty quickly grew to about $50 \mathrm{~nm}$. Consequently, two stable dimensions of nanoparticles were identified in the Room 3 during the photocopy operation, i.e. at about $50 \mathrm{~nm}$ and 80 nm (see March 25 and 26, 2014, Figure 5), which can be connected with the two different photocopy machines. Unfortunately, we did not follow separately the particle emissions of these two machines and so we cannot define the difference between them.
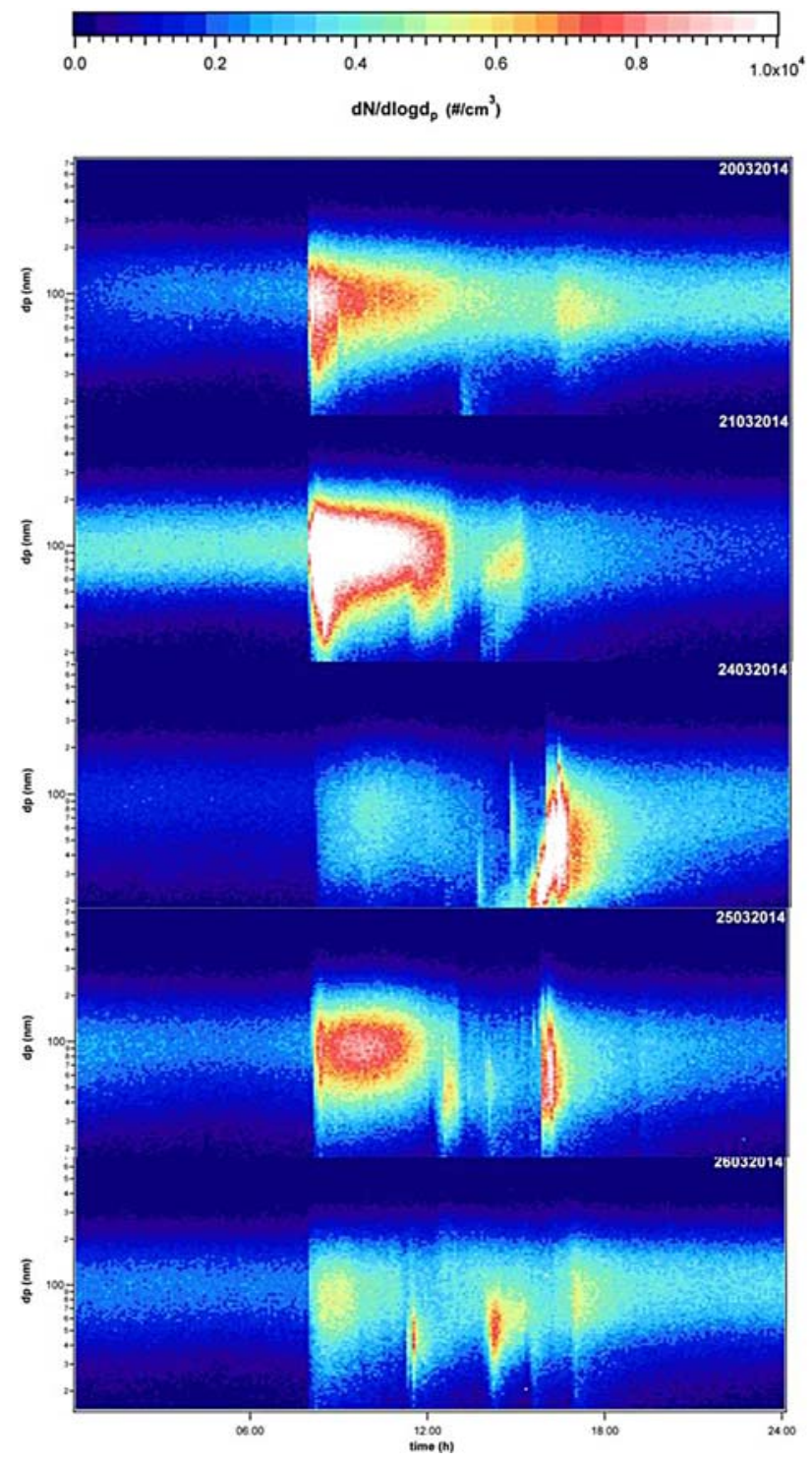

Figure 5: Number concentration (particle $\mathrm{cm}^{-3}$ ) and size distribution of the particles continuously measured in Room 3 of the company of spatial informatics and graphic design in Ljubljana, Slovenia from March 20 to March 26, 2014. White color represents the concentrations above $10 \times 10^{3}$ particle $\mathrm{cm}^{-3}$.

The rapid and sharp increase in the total particle number concentration up to more than $13 \times 10^{3}$ particle $\mathrm{cm}^{-3}$ immediately after starting the photocopy operation can be seen in Figure 3 c. After closing (at 16:00 on Friday) the total number concentration decreased to $1 \times 10^{3}$ particle $\mathrm{cm}^{-3}$. The average total number concentration du- 
ring the working hours for the 5 working days varied between 3.6 and $6.1 \times 10^{3}$ particle $\mathrm{cm}^{-3}$. Anyway, it can be concluded that the characteristic peak concentrations of nanoparticles were associated with the intensive photocopying operation.

Our results confirmed that during the operation of both, laser printers and photocopy machines high concentrations of nanoparticles with the size below $50 \mathrm{~nm}$ (around 20 or $30 \mathrm{~nm}$ ) were emitted into the indoor environment immediately at the beginning of printing and photocopying. It was already shown that the particles are formed in the air from VOCs and SVOCs strongly volatilized from the toner on the heating belt, and this can also be the reason of the intense "burst" of particles., ${ }^{7,10}$ Two possible mechanisms of ultrafine particles formation are discussed in the literature: ${ }^{7-9}$ a) homogeneous nucleation of SVOCs, which are released at high temperature and then condense at low temperature to form particles and $b$ ) secondary particle formation via oxidation of VOC with ozone, but also with other oxidants such as $\mathrm{NO}_{\mathrm{x}}$ and $\mathrm{OH}$ radicals, which can also release during photocopying. ${ }^{9}$

As it has been found during our measurements the small particles of the size below $50 \mathrm{~nm}$ relatively quickly grew to bigger sizes and persisted in the indoor environment for days. The reason for this situation can be ascribed undoubtedly to the inadequate ventilation, what was confirmed with measurements in the rooms with laser printers (Figures 2 and 4). In the photocopy room (Room 3) the situation was different, although again with a sharp increase in the concentration of small particles (around $20 \mathrm{~nm}$ ) and their fast growth to bigger sizes, the particle concentration afterward in a certain time after closing decreased to the background concentration (Figure 5). This was certainly because of much better ventilation, at least each morning the window was opened to let it in the ambient air. By this we are also pretty sure that during the indoor particle measurements no particular influence of the outdoor nanoparticles could be noticed.

It is known, that the amount of emitted particles can depend on many different factors, such as type of printer, toner coverage, cartridge age, etc., ${ }^{3}$ however, it was not in our scope to get the information on emissions of nanoparticles for particular laser printer or photocopy machine as well. In addition, it was also not feasible to exclude the other sources (i.e. plotters), especially in the Room 2. However, our results on concentrations of nanoparticles generated by laser printers and photocopy machines are very important, especially from the point of indoor air quality and exposure of people in such workplace environment.

\section{Conclusions}

The indoor pollution of a printing and photocopy center in Ljubljana, Slovenia was investigated for the first time. Our results obtained by continuous measure- ments of the particle number concentrations and the particle size distributions in one month period confirmed that during operation of laser printers as well as photocopy machines the total number concentration of nanoparticles (size between 15 and $750 \mathrm{~nm}$ ) in the surrounding air increased and reached up to $17 \times 10^{3}$ particle $\mathrm{cm}^{-3}$. During the operation of laser printers the bimodal particle size distribution was frequently observed, with the persisting aged particles in the room over the night and even over the weekend. In the room with two photocopiers a sharp increase in the concentration of particles of about $20 \mathrm{~nm}$ with their immediate growth to bigger sizes was observed. However, after closing a decrease to the background concentration was found. The results undoubtedly proved that the fast increase in nanoparticles (size below $50 \mathrm{~nm}$ ) was associated with both processes: the intense printing and photocopying activity. Our study also confirmed that a very important factor which affects the life time of aged nanoparticles in the indoor environment is the ventilation of the room, i.e. with inadequate ventilation the particles of the size of about $100 \mathrm{~nm}$ remained elevated for days.

\section{Acknowledgement}

The authors wish to thank the Slovenian Research Agency (Contract no. P1-0034-0104) for funding the research and to Peter Kastrin for his experimental support.

\section{References}

1. N. Kagi, S. Fujii, Y. Horiba, N. Namiki, Y. Ohtani, H. Emi, H. Tamura, Y. S. Kim, Build. Environ. 2007, 42, 1949-1954. http://dx.doi.org/10.1016/j.buildenv.2006.04.008

2. C. W. Lee, D. J. Hsu, Atmos. Environ. 2007, 41, 6598-6609. http://dx.doi.org/10.1016/j.atmosenv.2007.04.016

3. C. He, L. Morawska, L. Taplin, Environ. Sci. Technol. 2007, 41, 6039-6045. http://dx.doi.org/10.1021/es063049z

4. T. Schripp, M. Wensing, T. Salthammer, C. He, L. Morawska, Environ. Sci. Technol. 2008, 42, 4338-4343. http://dx.doi.org/10.1021/es702426m

5. A. J. Koivisto, T. Hussein, R. Niemelä, T. Tuomi, K. Hämeri, Atmos. Environ. 2010, 44, 2140-2146. http://dx.doi.org/10.1016/j.atmosenv.2010.02.023

6. T. Salthammer, Chemosphere 2011, 82, 1507-1517. http://dx.doi.org/10.1016/j.chemosphere.2010.11.023

7. M. Wensing, T. Schripp, E. Uhde, T. Salthammer, Sci Tot. Environ. 2008, 418-427.

8 . L. Moravska, C. He, G. Johnson, R. Jayaratne, T. Salthammer, H. Wang, E. Uhde, T. Bostrom, R. Modini, G. Ayoko, P. McGarry, M. Wensing, Environ. Sci. Technol. 2009, 43, 1015-1022. http://dx.doi.org/10.1021/es802193n

9. C.-W. Lee, D.-J. Hsu, Atmos. Environ. 2007, 41, 6598-6609. http://dx.doi.org/10.1016/j.atmosenv.2007.04.016 
10. Z.-M. Wang, J. Wagner, S. Wall, Aerosol Sci. Tech. 2011, 45, 1060-1068.

http://dx.doi.org/10.1080/02786826.2011.580799

11. C. He, L. Morawska, H. Wang, R. Jayaratne, P. McGarry, G. R. Johnson, T. Bostrom, J. Gonthier, S. Authemayou, G. Ayoko, J. Aerosol Sci. 2010, 41, 523-530. http://dx.doi.org/10.1016/j.jaerosci.2010.02.015

12. M. Barthel, V. Pedan, O. Hahn, M. Rothhardt, H. Bresch, O. Jann, S. Seeger, Environ. Sci. Technol. 2011, 45, 7819-7825. http://dx.doi.org/10.1021/es201590q

13. T. Smola, H. Georg, H. Hohensee, Gefahrstoffe Reinhaltung Der Luft 2002, 62 (7-8), 295-301.

14. M. Khatri, D. Bello, P. Gaines, J. Martin, A. Pal, R. Gore, S. Woskie, Nanotoxicology 2012, http://dx.doi.org/10.3109/17435390.2012.691998

15. M. Khatri, D. Bello, A. K. Pal, J. M. Cohen, S. Woskie, T. Gassert, J. Lan, A. Z. Gu, P. Demokritou, P. Gaines, Part. Fibre Toxicol. 2013, 10:42 http://dx.doi.org/10.1186/1743-8977-10-42

16. O. Hänninen, I. Brüske-Hohlfeld, M. Loh, T. Stoeger, W. Kreyling, O. Schmid, A. Peters, J. Nanopart. Res. 2010, 12, 91-99. http://dx.doi.org/10.1007/s11051-009-9693-z

17. WHO, 2005, WHO Air quality guidelines for particulate matter, ozone, nitrogen dioxide and sulfur dioxide - Global update 2005 - Summary of risk assessment. World Health Organization, Geneva. http://www.euro.who.int/_data/assets/pdf_file/0008/147851/E87950.pdf

\section{Povzetek}

V nedavnih raziskavah so bili laserski tiskalniki in fotokopirni stroji opredeljeni kot pomembni viri onesnaževanja zraka v zaprtih prostorih z drobnimi in ultra drobnimi delci. V tem delu smo preučevali tovrstno onesnaževanje v zaprtih prostorih fotokopirnega in tiskarskega centra $v$ Ljubljani. Meritve številčne koncentracije delcev ter njihovo porazdelitev po velikosti smo izvajali neprekinjeno v obdobju enega meseca s spektrometrom za štetje submikronskih delcev (SMPS). Naše meritve so jasno pokazale povečanje celokupne številčne koncentracije nanodelcev (velikost med 15 in $750 \mathrm{~nm}$ ) med delovnim časom $\mathrm{v}$ obeh prostorih z laserskimi tiskalniki kot tudi v sobi z fotokopirnimi stroji. V prostorih z laserskim tiskalnikom je bila pogosto opažena bimodalna porazdelitev velikosti delcev (z maksimumoma pri približno 20 ali $30 \mathrm{~nm}$ in pri približno $100 \mathrm{~nm}$ ), pri čemer so se očitno »stari« delci zadrževali v sobi tudi čez noč in preko vikenda. V sobi s fotokopirnimi stroji je bila situacija drugačna. Sicer smo spet opazili izrazito povečanje koncentracije majhnih delcev (ca. $20 \mathrm{~nm}$ ) in njihovo rast do večjih velikosti, vendar se je koncentracija delcev po koncu obratovanja zmanjšala na vrednost koncentracije ozadja. Rezultati so nedvomno dokazali, da je hitro povečanje koncentracije nanodelcev (velikosti pod $50 \mathrm{~nm}$ ) povezano s procesi, z intenzivnim laserskim tiskanjem in fotokopiranjem. Naša raziskava je tudi potrdila, da je prezračevanje prostora zelo pomemben dejavnik, ki vpliva na življenjsko dobo »staranih « nanodelcev v notranjem okolju. 